\title{
Gerald S. Maryanov
}

$1927-1975$

On November 30, 1975 Gerald (Jay) Maryanov died of cancer. Jay's professional career was devoted to the understanding of Southeast Asia, particularly Indonesian and Malaysian societies. As a Professor of Political Science at the universities of Illinois and Iowa, and since 1967 at Northern Illinois University, Jay taught hundreds of students to have a keener appreciation of and feeling for the peoples of Southeast Asia. He avoided ethnocentric approaches and insisted that his students analyze this area from the point of view of the Southeast Asian. His incisive publications on Southeast Asia and political science are representative of his innovative scholarship.

Jay's active involvement in Southeast Asian studies began in 1953 when he first went to Indonesia with the Ford Foundation; he returned to that area on several occasions for field research and post-doctoral work. In 196I-1962 he served as the Peace Corps Representative in Malaya. He was the Southeast Asia editor for the Association for Asian Studies Newsletter, and was an elected member of the Association's Southeast Asia Regional Council. He was chairman of SEARC's Committee on Professional Development and was also a member of the AAS Committee on Ethics. His most recent publication, The Condition of Southeast Asian Studies in the United States: 1972, is a comprehensive analysis that shows remarkable knowledge of the scholarship on South. east Asia.

Jay leaves behind his wife Mona and his two sons Michael and David, ages seven and six. His professional legacy includes a large group of students and colleagues who have had the privilege of learning from and knowing him.

A Gerald S. Maryanov Memorial Library Fund has been established. Funds may be sent to the NIU Foundation, Northern Illinois University, DeKalb, Illinois Gorss.

Northern Illinois University

Clark D. Neher 